\title{
Aesthetic Perception Scale: Validity and Reliability Study
}

\section{OPEN ACCESS}

Volume: 9

Special Issue: 2

Month: September

Year: 2021

E-ISSN: 2582-1334

Received: 12.07.2021

Accepted: 20.08.2021

Published: 15.09.2021

Citation:

Karaca, Nuray, and Abdulselami Sarıül.

"Aesthetic Perception

Scale: Validity and

Reliability Study." Shanlax

International Journal of

Education, vol. 9, no. S2,

2021, pp. 9-23.

DOI:

https://doi.org/10.34293/

education.v9iS2-Sep.4367

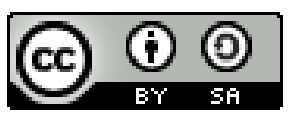

This work is licensed under a Creative Commons Attribution-ShareAlike 4.0 International License

\section{Nuray Karaca}

Atatürk University, Turkey

https://orcid.org/0000-0003-0215-9325

\author{
Abdulselami Sarıgül \\ A ̆̆r İbrahim Çeçen University, Turkey \\ https://orcid.org/0000-0002-1272-5274
}

\begin{abstract}
The aim of this study is to build a measurement tool to survey the aesthetical development of the social network "Instagram" on women and to define its psychometrical qualities. The research is a descriptive and quantitative study designed with a screening model. This Aesthetic Perception Scale is based on a proper literature survey and expert opinions. Purposive and criterion sampling methods were used while determining the sampling of the study.716 women studying in the cities of A ̆grl, Erzurum, Istanbul and İzmir were involved in the study. The data were collected via scale, which was developed by the researcher. Explanatory factor analysis was conducted within the research in order to present proves for the findings of the measurement tool. A scale of three factors and 36 items was developed at the end of the research. In order to present proof for the reliability of the data collected by the scale; Cronbach Alpha $(\alpha)$ reliability co-efficients were calculated. As a result, it is found that the scale is a valid and reliable tool of measurement in its field. Therefore; this respective measurement tool is recommended to be used while defining the aesthetical perceptions of women.
\end{abstract}

Keywords: Aesthetical perception, Instagram, Consumption.

\section{Introduction}

With the ongoing progress in the area of technology; the newly emerging social media applications have started to take more and more place in our lives. Social media has been uniting people -and especially the new generationseeking to get together with crowds in a social environment, adopting a social life. People have been finding what they were looking for on various applications and eventually the variety of the applications assembled people together on social media. (Kross, et al. 2021, pg.55-60).

Social media applications could be defined as softwares specially designed for sharing and following posts of videos, pictures, meals, travels, conversations and many more about people (Bhandarkar, et al. 2021, p.35-42). Although, in the beginning the first users of social media were perceived as unsociable, this idea had lately become extinct and social media people were acknowledged to be socialising merely with different means. Overtime; social media has even had further impact on economy rather than social institutions and become a tool of product advertisement and sales. (Pavithra and Deepak, 2021, p.15). Nevertheless, the impact of social media was not only on the economy. Various studies of today demonstrate that it had serious impact on educational institutions, too (Öztürk and Talas, 2015;Sarsar, Başbay and Başbay, 2015). Important studies were conducted with an attempt to utilize social media applications in the field of education. (Manu, et al, 2021, p.1-9). This situation shows that social media is not only an entertainment tool today, but also a new living space with many sociological institutions. 
As social media enveloped the social structure, it created new forms of relationships, identities and a new language. And a new socialisation was ensured by the transfer of this new form from the old users to the new ones; creating a new culture of itself. (Elsaesser, et al., 2021, p.2-8). This new culture has turned social media into an indispensable new habitat for people.

"We are social Hootsuite" sharesannual internet and social media utilisation rates every year. According to their 2020 rates, Instagram was the 3rd mostly preferred social media application with a total of 1 billion users around the world most of which are from the USA. There are 38 million users in Turkey which makes it the 6th on the worldwide list. Furthermore, Turkey is almost on all the top ten lists of social media user ratings and is said to be one of the top countries using Instagram application in Europe. (https://medyaakademi.com. tr/2020/02/03/2020-sosyal-medya-kullanici-sayilari/ access, 13:16, 26.02.2021).In the light of the social media user ratings it seems that almost half of the 80 million population in Turkey ( 1 of every 2 people in other words) use Instagram application. That is a valuable information underlining the fact that social media is a digital platform today addressing to all age segments with various and multiple concepts. No matter which age segment prefers whichever social media application; it is a fact that almost everyone is situated within this structure somehow. (O'Regan, et al. 2017, p.112-116).

According to the study by Demiral and Hassan (2020, p.361-362) Turkey, -when compared with European countries- has a higher rate of using social networks and keeping online during the day. Study also suggests that offering practical every day solutions, accessibility, aestheticism and comfort are the main motives when it comes to choosing the best social media apps. (Demiral and Hassan, 2020, p.361-362). In addition, Nardalı and Balkan's study (2019, p.178) states that according to the relevant research made on the substance; Instagram is the most effective social media application for launching new products in the market. From a sexual point of view the respective literature indicates young women's tendencyto show further attempt to be noticed, attracted, liked and seen causeInstagram to have a deeper impact on young ladies. (Kandil, 2019, p.3). This is no new news. Traditional media organs have always been using female body and objectificating it by constantly defining a perfect female body. TV projects on cosmetics, aesthetic operations, diets, fitness, fashion or aerobics have always indicated a perfect female body alienating those who do not have such physical properties and socially differentiating them with a feeling of deficiency. It is a well-known fact that women have gone thru various aesthetic operations, tough diet programs, and cosmetic support to cope with it. (Suiçmez, 2018, p.67-68).

Cosmetics and textile industries have been explicitly using this aspect of women seeking beauty and a good appearance. Iconic social media accounts (social media phenomenon) play a key role advertising the cosmetic products to the women. This helps the market keep active all the time. Turkey is also the leading country launching cosmetic products thru those "phenomenon's". (Nardalı and Balkan 2019 , p.177). This is undoubtedly not limited to Turkey and is supported by a greater supranational economical structure according to. Hardt and Negri define this as an "empire" to define women and the concept of beauty supranationally by industries such as cosmetics, textiles, aesthetical medicine, and fitness all around the world. They call it as a new duty which basically requires one to "surpass the other" and state this not as something individual but a way of imperialism to position itself over the main power allowing it to reach every single person in each and every country one by one; all around the world flawlessly without any boundaries. (Hard and Negri 2012).

During the traditional era; the human body was believed to be a sacred entity gifted by god. However, with the modern times, it became like an object to be designed thanks to the technological developments. In these modern times the body is like an outfit: waiting to be shaped and formed as you like. (Şişman, 2012). This shows how the body is no longer static but constantly in need of being attended to and designed upon. (Baudrillard, 2016, p.164-165). Under such circumstances contemporary "power" did not leave the body alone. With growing imperialist powers, a "fluidity" was required in order forthe power to be present at multiple locations 
(including people's bodies) simultaneously. (Hardt and Negri, 2012, p.25-64). To achieve that in modern times everything traditional (the matter included) was evaporated and the fluidity in time and place was ensured (Bauman, 2019, p.25-33). In this context, each and every human body -as quoted by Foucultwas disciplined to become a conveyor of the main power. (Özmakas, 2018, p.57-70).

In these modern times, human body -deemed as important; dominated by the main power and obliged to be ruled- was not "left alone" but granted with some motivational elements (Foucault, 2015). Interferences with the body or the motivations laying behind the rectifications on the body have absolutely become important signs to comprehend the process itself. (Baudrillard, 2016, p.164-194). Bourdieu suggests the source of such a motivation to be appreciation. The body is the conveyor of various images and the source of differentiating symbols. Appreciation aims at being differentiated from the others and estranging oneself. Every outfit or product is correlated with a specific social class. Even the choice of exercise defines the sexes from the scratch. (Bourdieu, 2015, p.276-298). According to Girard, another motive to regulate one's own body is about mimetic inclinations (2010). This theory is based on a belief that the desires one pursues do not belong to him/her but s/he actually pursues the dreams of others assuming that they are his/hers. According to this theory, desire has a social aspect. As a recap; the things we desire do not belong to ourselves but are actually based on realizing other people's dreams (Girard, 2010, p.48-75). From this point of view; formation of women body does not belong to women themselves but could be defined as a common social expectation -such as the description of an ideal bodydesigned by fashion designers, cosmeticians, social media influencers' or aestheticians. The desire of women to be appreciated (Girard, 2010) and the need for differentiating oneself from the others within the society (Bourdieu, 2015) brought together the social media visibility with Instagram. One could say the engagement of appreciation and desire in Instagram has initiated new life styles. In this context; visuality stands out further on Instagram than any other social media. Women on Instagram compare themselves to the other users based on their level of physical attraction always focusing on their "shortages constantly tracking a fulfilment pattern (Couture Bue, 2020, p.1817-1818). This state of imperfection leads to an infinite body reformation. Considering from this perspective, social media sets a role model in terms of women body reformation; like a preferred stage for the body subject to that formulation. A measurement tool is necessary in this field. Therefore, the purpose of this study is to establish an Aesthetic Perception Scalein order to fulfil this sociological gap as well as analysing psychometrical aspects of its.

\section{Objective of the Study}

The aim of this research is to develop a new measurement tool to define whether the use of Instagram affects women's aesthetically personal designs; and to contribute to the field of sociology by confirming the validity and reliability of this new Aesthetic Perception Scale.

\section{The Method \\ The Research Model}

The purpose of this study is to develop an Aesthetic Perception Scale tool and define psychometrical aspects of it. The research is a descriptive and quantitative study designed with a screening model. Screening studies are defined as a display ofexisting situations as they are. (Karasar, 2012).

\section{Scale Development Process \\ Establishing The Item Pool}

In this study; a pre-test was carried out in order to establish the item pool. With this purpose; a pretest study was performed with 20 university students that represent the targeted system. This pre-test was conducted face to face. The items on draft scale could be comprehended and filled out accordingly by the attendants in 15 minutes.

An item pool was established to measure the structure of this research which aims at determining the aesthetical impact of Instagram on women body. During the process of establishing the item pool; the respective literature was reviewed. The motives and the purposes for women to use Instagram was also studied. measurement tools used previously regarding other and/or similar social media 
applications were reviewed and utilized. (Turan, 2019; Zümrüt,2016). Furthermore, few theories from relevant literature were reviewed to analyse the structure sociologically (Baudrillard, 2016; Bauman, 2017; Bourdieu, 2015; Castellls, 2008; Castells, 2013; Dağ, 2018; Foucalut, 2015; Girard, 2010; Hardt and Negri, 2011; Hardt and Negri, 2012; Sennet, 2013). 114 items were initially writed after all those reviews and readings.. Following that; 2 experts with $\mathrm{PhD}$ degree in sociology and an assessment and evaluation specialist made a preview and considered some of the items as inadequate in terms of measuring the corresponding structure. And they also found out that some of the items were identical on the measurement tool. In this context; the measurement tool was revised and reduced to 73 items. It is a Likert measurement tool and designed for self-examination. The tool was 5-level-rated as "absolutely agree", "agree", "indecisive", "do not agree" and "absolutely do not agree".

\section{Taking Expert Opinion}

After completing the item pool; expert opinion was required in order to prove the context validity of the measurement tool. In this regard; a total of 13 expert opinions were taken (being 7 experts from the field of Sociology, 1 as assessment and evaluation specialist, 2 experts from the field of teaching Turkish language, another one from psychological counselling and guidance, and 2 more experts from Psychology) in order to assess the legibility and compliance of the draft items prepared for the Aesthetic Perception Scale (APS).7 of the experts had their PhD degrees. Those experts were presented an expert evaluation form on which they were asked to rate each item on the measurement tool as (1) as relevant, (2) relevant but needs improvement and (3) for irrelevant. Law she (1975) approach was adopted while evaluating the content validity of those items and the number of 13 experts were taken into account for calculating the content validity rate (CVR). The lowest critical value was found out to be 0,544 (for $\mathrm{p}=0.05$ - Wilson, Pan and Schumsky, 2012). All items were calculated regarding their CVR values and as a result; 9 of the items rated below 0,544 were eliminated off the form. Eventually 64 items were maintained on the form.

\section{Application}

A preliminary trial was conducted to determine the comprehensibility of the 64 items by women at the university and also in order to define the duration of the application of the Aesthetic perception scale to them. A preliminary trial was conducted to 20university student women who showed the same characteristics as the target study population. In this preliminary assessment performed face to face, it was determined that the scale was understood by the students; and that the test exam and could be completed in approximately 15 minutes.

\section{Study Group}

In the framework of the pilot application of the scale draft prepared, the two-step sampling method was used. Since the population of the study to be conducted is women, in the first step, the cities of Istanbul, Izmir, Erzurum and Ağrı were determined in light of the intentional sampling method. The reason for choosing these cities is that they allow the comparison between the east and the west of Turkey, and even though the literal meaning in this comparison is as seen by everyone, it allows regional socioeconomic and sociocultural sociological evaluation in connotation. In addition, it was aimed for the researcher to reach the sample more easily during the pandemic period. In the second step, in accordance with the purpose of the study, the women for sampling were selected based on their level of higher education and their use of Instagram. For this purpose, a total of 716 people, 216 in Istanbul, 193 in Izmir, 165 in Erzurum and 142 in Ağr1, voluntarily participated in the study. As a result of the preliminary examination, it was determined that some of the participants did not use Instagram, and therefore the research was carried out with a total of 689 people, 208 in Istanbul, 184 in Izmir, 158 in Erzurum and 139 in Ağrı. During the data clearing phase, the data of 14 women who did not respond to the items to a large extent and were out of \pm 3 values as a result of the extreme value calculations were excluded from the analysis, and the data were calculated with a total of 676 people. Intentional sampling method is a frequently preferred method in scale development studies. In addition to these, it is stated that it is necessary to consider the design 
of the scale, its structure and the technique to be used in the analysis of the data, especially in cases of scale development to be reconstructed other than adaptations (Erkuş, 2012). At the beginning of the pilot implementation phase of the work to be carried out; in order to work with a sample that can represent the subject being measured, it is aimed to reach as many people as possible in a more economical and simple way by using intentional sampling method. The principle of including ten people for each item in the scale study, which is used as a general principle for exploratory factor analysis in studies of scale type; as an example, it was stated that a sample of 100 people is required for a 10 -item study to be used in the scale (Akgül, 1997; Culha, 2016, p. 106;). Therefore, the number of women participating in the study was specifically intended to be at least 10 times the number of items in the scale, taking into account the validity and reliability data analysis to be made on the results to be derived from the measurement data. It is stated in the literature that the number of women to participate in the study must be at least 5 times the number of items in the scale in order to carry out Explanatory Factor analyses to find evidence for direct construct validity (Büyüköztürk, 2012). In the context of the study, the information and findings of some socio-demographic conditions of the pilot group are given in Tables 1 and 2 .

Table 1: Frequencies and Percentages of the Demographic Information of Instagram user Participants Selected for the Trial / Pilot Study Group

\begin{tabular}{|c|c|c|c|}
\hline Variable & Category & f & $\%$ \\
\hline \multirow{5}{*}{ Have been an Instagram user for... } & $1-2$ years & 152 & 22,5 \\
\hline & $3-4$ years & 202 & 29,9 \\
\hline & $5-6$ years & 241 & 35,6 \\
\hline & $7-8$ years & 61 & 9,0 \\
\hline & $9-10$ years & 20 & 3,0 \\
\hline \multirow{5}{*}{ Daily online hours spent on Instagram } & $1-3$ hours & 285 & 42,2 \\
\hline & 4-6 hours & 314 & 46,5 \\
\hline & 7-9 hours & 65 & 9,6 \\
\hline & 10 hours and more & 11 & 1,6 \\
\hline & N/A & 1 & 0,1 \\
\hline \multirow{2}{*}{ Does the profile name match the real name } & Yes & 606 & 89,6 \\
\hline & No & 70 & 10,4 \\
\hline \multirow{2}{*}{ Is that you on the profile photo } & Yes & 554 & 82,0 \\
\hline & No & 122 & 18,0 \\
\hline \multirow{2}{*}{ Notifications turned on? } & Yes & 489 & 72,3 \\
\hline & No & 187 & 27,7 \\
\hline \multirow{2}{*}{ Accessible and non-private account } & Yes & 45 & 6,7 \\
\hline & No & 631 & 93,3 \\
\hline \multirow{2}{*}{ Re-activating the Instagram account } & Yes & 446 & 66,0 \\
\hline & No & 230 & 34,0 \\
\hline \multirow{2}{*}{ Owns a fake Instagram account } & Yes & 234 & 34,6 \\
\hline & No & 442 & 65,4 \\
\hline \multirow{5}{*}{ Number of followers on Instagram } & $0-250$ people & 99 & 14,7 \\
\hline & 251-500 people & 137 & 20,3 \\
\hline & 501-1000 people & 174 & 25,7 \\
\hline & 1001-5000 people & 261 & 38,6 \\
\hline & $5001-10,000$ people & 3 & 4 \\
\hline
\end{tabular}




\begin{tabular}{|l|l|c|c|}
\hline Number of followers on Instagram & 10,001 peopleor more & 2 & \multicolumn{1}{|c|}{2} \\
\hline \multirow{4}{*}{$\begin{array}{l}\text { Total number of accounts she is following on } \\
\text { Instagram }\end{array}$} & $0-50$ people & 39 & 5,8 \\
\cline { 2 - 4 } & $51-100$ people & 102 & 15,1 \\
\cline { 2 - 4 } & $101-200$ people & 177 & 26,2 \\
\cline { 2 - 4 } & $201-300$ people & 193 & 28,6 \\
\cline { 2 - 4 } & $301-500$ people & 106 & 15,6 \\
\cline { 2 - 4 } & 501 people or more & 59 & 8,7 \\
\hline \multicolumn{2}{|c|}{ Total } & 676 & 100,00 \\
\hline
\end{tabular}

When Table 1 is examined, it is seen that the total years of using Instagram is maximum between 5 and 6 years and is minimum between 9 and 10 years. When the daily online hours are examined, we see that approximately half of the participants use it for 1 to 2 hours and the other half for 3 to 4 hours. The majority of the group has their own name and surname and an Instagram account with their own photo. While most of the participants keep their notifications on; they also pay attention to their privacy. The majority of the participants turned off and reactivated their accounts. When the distribution is examined according to the number of followers, it is observed that the maximum number of followers is between 1001 and 5000, while the minimum is between 0 and 50 people. When we examine the number of people that the women follow; we see that maximum number of people followed is between 201-300 people, while minim is $0-50$ people in this regard.

Table 2: Frequencies and Percentages of Participants' Demographics that are Selected for the Trial / Pilot Study Group

\begin{tabular}{|c|c|c|c|}
\hline Variable & Category & f & $\%$ \\
\hline \multirow{4}{*}{ City were her university is located } & İstanbul & 201 & 29,7 \\
\hline & İzmir & 183 & 27,1 \\
\hline & Erzurum & 155 & 22,9 \\
\hline & Ağr1 & 137 & 20,3 \\
\hline \multirow{7}{*}{ Industry where monthly income is mostly spent } & Clothing & 274 & 40,5 \\
\hline & Personal hygiene\& make-up & 174 & 25,7 \\
\hline & Social Activities & 32 & 4,7 \\
\hline & Cultural Activities & 13 & 1,9 \\
\hline & Travel and holidays & 13 & 1,9 \\
\hline & Educational Expenses & 148 & 21,9 \\
\hline & Other & 22 & 3,4 \\
\hline \multirow{4}{*}{$\begin{array}{l}\text { Total amount of clothing, make-up, accessories, } \\
\text { jewellery and hairdresser expenses/month }\end{array}$} & Between 0-500 TL & 433 & 64,1 \\
\hline & Between 501-750 TL & 114 & 16,9 \\
\hline & Between 751-1000 TL & 124 & 18,3 \\
\hline & $1001 \mathrm{TL}$ and more & 5 &, 7 \\
\hline \multirow{5}{*}{ Faculty attended } & Literature & 189 & 28,0 \\
\hline & Medical Sciences \& Health & 358 & 53,0 \\
\hline & Technical Faculties \& Engineering & 43 & 6,4 \\
\hline & Applied Sciences & 65 & 9,6 \\
\hline & Other & 21 & 3,0 \\
\hline \multirow{2}{*}{ Monthly Budget } & Between 0-650 TL & 195 & 28,8 \\
\hline & Between 651-1300 TL & 163 & 24,1 \\
\hline
\end{tabular}




\begin{tabular}{|c|c|c|c|}
\hline \multirow{3}{*}{ Monthly Budget } & Between 1301-2000 TL & 174 & 25,7 \\
\hline & Between 2001-3000 TL & 94 & 13,9 \\
\hline & $3001 \mathrm{TL}$ and more & 50 & 7,4 \\
\hline \multirow{4}{*}{ Family based in...... } & City Centre & 326 & 48,2 \\
\hline & County Centre & 211 & 31,2 \\
\hline & Town & 19 & 2,8 \\
\hline & Village Centre & 120 & 17,8 \\
\hline \multirow{6}{*}{ Age } & Between 17-19 & 145 & 21,4 \\
\hline & Between 20-22 & 357 & 52,8 \\
\hline & Between 23-25 & 105 & 15,6 \\
\hline & Between 26-28 & 26 & 3,8 \\
\hline & Between 29-31 & 18 & 2,7 \\
\hline & 32 and up & 25 & 3,7 \\
\hline \multicolumn{2}{|c|}{ Total } & 676 & 100,00 \\
\hline
\end{tabular}

When Table 2 is examined, it is seen that the distribution of the participants per city is close to each other. It has been found out that the participants allocate their income mostly to clothing, then personal care and make-up, and least to cultural activities and travels. Considering the distribution of the amount of money that the participants spend on clothes, jewellery, make-up and hairdressers per month, it was determined that the majority of the group spent between 0-500 TL. It is seen that the majority of the participants in the study attend to the faculties of Medicine and health sciences and only a minority attend to the Engineering and Technical faculties. When the monthly budgets of the participants are examined, it is seen that they are close to each other. It was determined that approximately half of the participants lived in the city centre and one third lived in the county centre. Looking at the distribution by age, it is clear that about half of them are between 20-22 years old and only a few are between 29-31.

\section{Data Analysis}

In the study, the final version of the scale consisting of 64 items was applied to the study group in the pilot application, and one of the factor detection methods, "Principal Component Analysis" was used to determine the factor structure of the scale prepared on the data. Kaiser-Meyer-Olkin (KMO) and Barlett globularity tests were used to measure the compatibility of the resulting data with factor analysis. It is explained that the Barlett Globularity
Test is statistically significant considering that the items in the scale are related to each other and the matrix of the data is suitable for factor analysis. It is also explained that the Barlett Globularity Test is statistically significant considering that the Kaiser-Meyer-Olkin values are 0.50 and above, (Büyüköztürk, 2012; Field, 2009). In determining the number of factors to be used in the scale, the scree plot, the eigen values of the factor, the opinions and suggestions of the experts and the contents of the scale items were taken into consideration. It was deemed appropriate to take the limit value of 0.32 for factor loadings, which is considered as evidence of the connection of all individual items with the relevant factor (Tabachnick \& Fidell, 2013). Items with a load below these rates were excluded from the scale. While performing factor analysis for the scale, rotation was used as a method. While using rotation, both oblique rotation and vertical rotation methods were collected and the items in the tested scale were collected and aggregated in a meaningful way by varimax rotation method. The Cronbach Alpha $(\alpha)$ number was calculated as the reliability coefficient in order to prove the reliability of the measurement results obtained in the study.

While reporting the item-total correlation coefficients in the scale, the indicator of item discrimination was taken as evidence. When evaluating the internal consistency data coefficient in the scale, the value of the reliability coefficient of 0.70 or above is interpreted as reliable. (Salvucci, 
et al., 1997). Internal consistency, item-total correlation data coefficient value of 0.20 and above indicates that each item works in harmony with the whole scale (Crocker \& Algina, 2006). SPSS 25 statistical program was used for data analysis and calculations in the context of the study.

\section{Ethical Compliance}

While conducting the actual implementation and pilot study of this research, publication ethics rules were followed and the study was not sent to other journals for evaluation. The compliance of the research with ethical principles has been documented by the ethics committee verdict. The participants were informed that they should behave honestly and sincerely while answering the questions and that the data obtained in the research would not be abused.

\section{Findings}

Kaiser-Meyer Olkin and Barlett globularity test were conducted during the pilot application of the study to check whether the data were suitable for factor analysis. The resulting findings are presented in Table 3.

Table 3: KMO and Barlett Test Results

\begin{tabular}{|l|c|c|}
\hline Kaiser-Meyer-Olkin (KMO) & & 0,90 \\
\hline \multirow{3}{*}{ Barlett Test } & $\chi^{2}$ & 13884,23 \\
\cline { 2 - 3 } & $\mathrm{sd}$ & 2016 \\
\cline { 2 - 3 } & $\mathrm{p}$ & 0,000 \\
\hline
\end{tabular}

When Table 3 is examined, it is seen that the $\mathrm{KMO}$ value is 0.90 . Accordingly, it shows that the data has a factorizable structure (Field, 2009). When the Barlett globularity test results are examined, it is seen that the resulting data is statistically significant $\left(\chi^{2}=13\right.$ 884.23; $\left.p<0.05\right)$. The resulting value clearly shows that all of the items on the scale are related to each other. Along with these, the significance in the values of the globularity test is explained as it carries multivariate normality (Büyüköztürk, 2012). In order to determine the factor structure of the data obtained in the pilot study of the research, its suitability was tested and then the Exploratory factor analysis was performed without applying any restrictions to the number of factors. After testing the suitability of the obtained data for factor analysis, in the first step,
Explanatory Factor Analysis was performed without any restrictions. In the data found, it was observed that there were 15 factors with an eigen value above 1 in the first stage. The eigen values and explained variances for all factors are given in Table 4 with their rates.

Table 4: Eigenvalue, variances and Total Explained Variance Rates

\begin{tabular}{|c|c|c|c|}
\hline Factors & $\begin{array}{l}\text { Eigen } \\
\text { value }\end{array}$ & $\begin{array}{c}\text { Explained } \\
\text { variance }(\%)\end{array}$ & $\begin{array}{c}\text { Total } \\
\text { explained } \\
\text { variance }(\%)\end{array}$ \\
\hline 1 & 11,97 & 18,70 & 18,70 \\
\hline 2 & 3,73 & 5,83 & 24,53 \\
\hline 3 & 2,68 & 4,19 & 28,72 \\
\hline 4 & 2,09 & 3,27 & 31,99 \\
\hline 5 & 1,95 & 3,05 & 35,04 \\
\hline 6 & 1,75 & 2,74 & 37,77 \\
\hline 7 & 1,54 & 2,40 & 40,17 \\
\hline 8 & 1,41 & 2,21 & 42,38 \\
\hline 9 & 1,38 & 2,15 & 44,54 \\
\hline 10 & 1,32 & 2,05 & 46,59 \\
\hline 11 & 1,27 & 1,98 & 48,58 \\
\hline 12 & 1,21 & 1,89 & 50,47 \\
\hline 13 & 1,09 & 1,69 & 52,16 \\
\hline 14 & 1,06 & 1,66 & 53,82 \\
\hline 15 & 1,05 & 1,64 & 55,46 \\
\hline
\end{tabular}

As shown in Table 4, a total of 15 factors emerged with an eigen value above 1 . The eigenvalue of the first factor is 11.97 and the variance value explained by this first factor alone is $18.70 \%$. The total revealed variance rate explained by the 15 factors obtained in the study is approximately $55 \%$. When the eigen values of the related factors are considered, it is observed that the rate of decrease in the eigen value after the third factor decreases. In order to determine the number of factors to be included in the scale, the scatter plot of the eigen values was also carefully examined. 


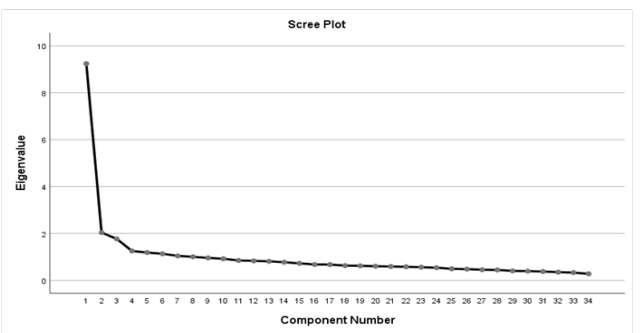

Chart 1: The Scatter Plot of Factor Eigen Values

As shown in Figure 1, it is seen that the main refraction in the eigen values themselves is between the first factor and the second factor. In the scatter plot, it is observed that the distance between the eigen values decreases especially after the third factor and they are very close to each other. Considering the expert opinions about the scale, the results of Explanatory Factor Analysis and the theoretical structure, it was decided that the number of factors that should be in the scale should be three.

After determining the number of factors related to the scale, the Exploratory Factor Analysis was reanalysed by fixing it to three factors. The Varimax rotation method was preferred in order to understand more clearly to which factor the items were loaded. When the findings obtained in the scale were examined, four items (m3, m6, m62, m64) listed below 0.32 and 24 items $(\mathrm{m} 1, \mathrm{~m} 2, \mathrm{~m} 12, \mathrm{~m} 15, \mathrm{~m} 17)$ that loaded on more than one factor (overlapping item) , m18, m19, m21, m22, m24, m26, m31, $\mathrm{m} 32, \mathrm{~m} 33, \mathrm{~m} 34, \mathrm{~m} 35, \mathrm{~m} 36, \mathrm{~m} 38, \mathrm{~m} 42, \mathrm{~m} 54, \mathrm{~m} 58$, $\mathrm{m} 60, \mathrm{~m} 61, \mathrm{~m} 63$ ) have been removed from the corresponding measuring tool. The final version of the measurement tool consists of a three-factor structure and 36 items.

Table 5: Factor Load Values, Eigen Values and Explained Variance Rates of the Final Aesthetic Perception Scale

\begin{tabular}{|l|c|c|c|c|c|c|}
\hline & \multicolumn{2}{|c|}{ Factor 1 } & \multicolumn{2}{c|}{ Factor 2 } & \multicolumn{2}{c|}{ Factor 3 } \\
\hline & $\begin{array}{c}\text { Item } \\
\text { Number }\end{array}$ & $\begin{array}{c}\text { Factor } \\
\text { Load }\end{array}$ & $\begin{array}{c}\text { Item } \\
\text { Number }\end{array}$ & $\begin{array}{c}\text { Factor } \\
\text { Load }\end{array}$ & $\begin{array}{c}\text { Item } \\
\text { Number }\end{array}$ & $\begin{array}{c}\text { Factor } \\
\text { Load }\end{array}$ \\
\hline & $\mathrm{m} 4$ & 0,69 & $\mathrm{~m} 16$ & 0,40 & $\mathrm{~m} 13$ & 0,58 \\
\hline & $\mathrm{m} 5$ & 0,71 & $\mathrm{~m} 20$ & 0,67 & $\mathrm{~m} 14$ & 0,47 \\
\hline & $\mathrm{m} 7$ & 0,41 & $\mathrm{~m} 23$ & 0,49 & $\mathrm{~m} 25$ & 0,50 \\
\hline & $\mathrm{m} 8$ & 0,66 & $\mathrm{~m} 27$ & 0,54 & $\mathrm{~m} 29$ & 0,46 \\
\hline & $\mathrm{m} 9$ & 0,36 & $\mathrm{~m} 28$ & 0,65 & $\mathrm{~m} 37$ & 0,38 \\
\hline & $\mathrm{m} 10$ & 0,51 & $\mathrm{~m} 30$ & 0,37 & $\mathrm{~m} 40$ & 0,33 \\
\hline & $\mathrm{m} 11$ & 0,52 & $\mathrm{~m} 39$ & 0,47 & $\mathrm{~m} 43$ & 0,40 \\
\hline & $\mathrm{m} 41$ & 0,53 & $\mathrm{~m} 51$ & 0,47 & $\mathrm{~m} 44$ & 0,33 \\
\hline & & & $\mathrm{m} 53$ & 0,46 & $\mathrm{~m} 45$ & 0,69 \\
\hline & & & $\mathrm{m} 55$ & 0,43 & $\mathrm{~m} 46$ & 0,68 \\
\hline & & & & & $\mathrm{m} 47$ & 0,68 \\
\hline & & & & & $\mathrm{m} 48$ & 0,67 \\
\hline & & & & & $\mathrm{m} 49$ & 0,63 \\
\hline & & & & & & \\
\hline
\end{tabular}


As seen in Table 5, the eigen value of the first factor is 1.79 and the variance value explained is approximately $5 \%$. It is seen that the factor load intervals of the first factor vary between 0.36 and 0.71 . The variance value explained by the second factor as 2.08 is seen as $5.77 \%$. Factor load ranges related to the second factor differ between 0.37 and 0.67 . The eigenvalue of the third and last factor is 9.73 and the variance ratio it explains is $27.04 \%$. The factor loading values of the items of the third factor differ between 0.33 and 0.69 . The total variance value explained for these three factors to be used in the scale is approximately $38 \%$. Considering the theoretical structures and item expressions used for the three factors used in this study, the first factor was named "Consumption", the second factor "Perception" and the third factor "Body and Aesthetics".

While calculating the relations of each factor used in the study with other factors and factor total score, Pearson Product Moment Correlation Coefficient was used and the findings of them are given in Table 6 .

Table 6: Pearson Moment Correlation Coefficient Values for the Relationships Between Factors

\begin{tabular}{|l|c|c|c|c|c|}
\hline & & Consumption & Perception & Body \& Aesthetics & Total \\
\hline \multirow{2}{*}{ Consumption } & $\mathrm{r}$ & 1 & & & \\
\hline & $\mathrm{p}$ & & & & \\
\hline \multirow{2}{*}{ Perception } & $\mathrm{r}$ & $0,50^{* *}$ & 1 & & \\
\hline & $\mathrm{p}$ & 0,000 & & & \\
\hline \multirow{2}{*}{ Body\& Aesthetics } & $\mathrm{r}$ & $0,60^{* *}$ & $0,65^{* *}$ & 1 & \\
\cline { 2 - 6 } & $\mathrm{p}$ & 0,000 & 0,000 & & \\
\hline \multirow{2}{*}{ Total } & $\mathrm{r}$ & $0,78^{* *}$ & $0,82^{* *}$ & 0,93 & 1 \\
\cline { 2 - 6 } & $\mathrm{p}$ & 0,000 & 0,000 & 0,000 & \\
\hline
\end{tabular}

$* \mathrm{p}<0,05 ; * * \mathrm{p}<0,01$

As shown clearly in Table 6, when the proportions are examined in general, the sub-dimensions of the scale show a moderate relationship with each other. Considering the relationship between the subdimensions of the scale and the total score of the scale, it is seen that this relationship is at a high level. While the consumption sub-factor has a correlation of $r=0.78$ with the overall scale, the correlation between the scores of the perception factor and the scores obtained from the calculations made with the overall scale is $r=0.82$, and the scores obtained from the body and aesthetics sub-factor, which is the last factor, are $r=0$ with the scores calculated for the overall scale. It appears to give a correlation of 93. These coefficients obtained are statistically significant at the level of 0.01 . The sub-factors of the scale are found to be highly correlated with the entire scale. This can be interpreted as the whole scale measures the same main structure with the subfactors.

In the study, exploratory factor analysis was performed in order to provide evidence for the construct validity of the measurements obtained from the Aesthetic Perception scale, and then the Cronbach's Alpha $(\alpha)$ reliability coefficient ratios were calculated in order to reveal the reliability of the obtained measurement results. Calculated findings are given in Table 7.

Table 7: Reliability Coefficient Values of the Measurement Results Obtained from the Sub-factors of the Aesthetic Perception Scale and Overall

\begin{tabular}{|l|c|c|}
\hline & N*$^{*}$ & Cronbach Alpha $(\boldsymbol{\alpha})$ \\
\hline Consumption & 8 & 0,775 \\
\hline Perception & 10 & 0,746 \\
\hline Body and Aesthetics & 18 & 0,888 \\
\hline \multicolumn{1}{|c|}{ Total } & 36 & 0,916 \\
\hline
\end{tabular}

$* \mathrm{~N}$ : number of items

As stated in Table 7, the resulting reliability coefficient values for the sub-factors and overall, of the scale were measured between 0.746 and 0.916 . The resulting data show that the measurement findings are highly reliable (Salvucci et al., 1997). In order to determine the final state of the aesthetic 
perception scale, item statistics were measured with

relevant data are given in Table 8 .

the rectified item-total correlation values and the

Table 8: Item statistics and Rectified Item-Total Correlation Values for the Final Version of the EPS

\begin{tabular}{|c|c|c|c|c|c|}
\hline Item Number & Item Avg. (X) & $\begin{array}{c}\text { Rectified } \\
\text { Item-Total } \\
\text { Correlation (r) }\end{array}$ & Item Number & Item Avg. (X) & $\begin{array}{c}\text { Rectified } \\
\text { Item-Total } \\
\text { Correlation (r) }\end{array}$ \\
\hline $\mathrm{m} 4$ & 2,70 & 0,22 & m39 & 2,40 & 0,61 \\
\hline $\mathrm{m} 5$ & 2,83 & 0,34 & $\mathrm{~m} 40$ & 2,02 & 0,47 \\
\hline $\mathrm{m} 7$ & 2,50 & 0,41 & $\mathrm{~m} 41$ & 2,52 & 0,55 \\
\hline $\mathrm{m} 8$ & 2,33 & 0,42 & $\mathrm{~m} 43$ & 2,03 & 0,50 \\
\hline $\mathrm{m} 9$ & 2,29 & 0,53 & $\mathrm{~m} 44$ & 2,26 & 0,49 \\
\hline $\mathrm{m} 10$ & 2,58 & 0,52 & $\mathrm{~m} 45$ & 1,91 & 0,49 \\
\hline $\mathrm{m} 11$ & 2,27 & 0,53 & $\mathrm{~m} 46$ & 1,82 & 0,61 \\
\hline $\mathrm{m} 13$ & 1,59 & 0,49 & $\mathrm{~m} 47$ & 1,75 & 0,50 \\
\hline $\mathrm{m} 14$ & 1,76 & 0,59 & $\mathrm{~m} 48$ & 1,80 & 0,53 \\
\hline $\mathrm{m} 16$ & 2,85 & 0,31 & $\mathrm{~m} 49$ & 1,63 & 0,61 \\
\hline $\mathrm{m} 20$ & 2,57 & 0,42 & $\mathrm{~m} 50$ & 1,83 & 0,57 \\
\hline $\mathrm{m} 23$ & 2,55 & 0,38 & $\mathrm{~m} 51$ & 2,90 & 0,47 \\
\hline $\mathrm{m} 25$ & 1,89 & 0,54 & $\mathrm{~m} 52$ & 1,77 & 0,60 \\
\hline $\mathrm{m} 27$ & 2,48 & 0,30 & m53 & 2,42 & 0,35 \\
\hline $\mathrm{m} 28$ & 2,08 & 0,51 & $\mathrm{~m} 55$ & 2,17 & 0,37 \\
\hline $\mathrm{m} 29$ & 2,05 & 0,51 & $\mathrm{~m} 56$ & 2,04 & 0,53 \\
\hline $\mathrm{m} 30$ & 2,69 & 0,30 & $\mathrm{~m} 57$ & 2,27 & 0,47 \\
\hline $\mathrm{m} 37$ & 2,27 & 0,29 & $\mathrm{~m} 59$ & 1,95 & 0,47 \\
\hline \multicolumn{3}{|c|}{ Item Average For Overall Scale } & : 2,22 & & \\
\hline \multicolumn{3}{|c|}{ Item Total Correlation Values For Overall Scale } & $: 0,24$ & & \\
\hline
\end{tabular}

As indicated in Table 8, the averages of the items in the scale vary between 1.59 and 2.90 values. The mean values of 2.22 items were reached for the overall scale. It is observed that the total correlation rates of the items differ between the values of 0.22 and 0.61 , and the average of the data for the total correlations of the items calculated for the whole scale is 0.24 . The fact that the coefficient values of item-total correlations for the whole of the scale are above 0.20 can be interpreted as that the items work in accordance with the whole test (Crocker and Algina, 2006).

\section{Discussion and Conclusion}

Social media applications, where communication and sharing are at the centre, have started to be at the centre of our lives with the effect of the Pandemic (Yıldırım and İpek, 2020, p. 69). With the introduction of social media into our lives, a new form of socialization has formed, social media has not only been virtual, but has become a structure that changes and transforms our lives. In addition, social media has managed to create a new lifestyle with its own concepts, influencers and the language of emoticons (Arklan and Akdağ, 2016, pp. 16$31)$. For these reasons, many people have started to meet their need to socialize through social media. As a result, social media has settled in the centre of many people's lives and has started to affect many aspects of our lives. Advertisements for the brands of businesses related to fashion, clothing and personal care products are now made through influencers. It can be said that the fact that these advertisements are made by such influencers following a natural process, not advertising, but advice, has made social media an important and liberal space in terms of 
women's aesthetic evaluations. All these processes have caused a significant incident; The intense effect of social media on women's aesthetic perceptions. In this context, the aim of the study is to develop a measurement tool that reveals the effect of Instagram on women's aesthetic perceptions. The Aesthetic Perception Scale (APS) developed for this purpose, consists of a total of three factors and 36 items. The eigen value of the first factor is 1.79 and the variance value it explains is approximately $5 \%$. It is seen that the factor load intervals of the first factor vary between 0.36 and 0.71 . The variance value explained by the second factor as 2.08 is seen as $5.77 \%$. Factor load ranges related to the second factor differ between 0.37 and 0.67 . The eigenvalue of the third and last factor is 9.73 and the variance ratio it explains is $27.04 \%$. The factor loading values of the items of the third factor differ between 0.33 and 0.69 . The total variance value explained for these three factors in the scale is seen as approximately $38 \%$.

It is seen that there is a difference between the values of 0.22 and 0.61 for the total correlation rates of the items under the scale factors. These values obtained in the study show that the scale items prepared on three factors are compatible with the whole of the scale (Crocker \& Algina, 2006). It is seen that the relationship levels between the dimensions of the scale vary between 0.78 and 0.93 . When the relationships among the scale factors are examined, it was found that they are moderately correlated with each other. Considering the relationship between the sub-dimensions of the scale and the total score of the scale, it is seen that this relationship is at a high level. This can be interpreted as the whole scale measures the same main structure with the sub-factors. It was measured that the reliability coefficients of the values obtained as a result of the scale analysis varied between 0.746 and 0.916 . These results for the subdimensions and general of the scale show that a highly reliable scale has been obtained (Salvucci et al.1997). "Consumption" factor comes first when we examine the aesthetic perceptions of women on social media by the items obtained with three relevant factors. The items in the first factor related to the scale include the motivation of using Instagram, the purpose of using Instagram, the effect of consumption and technology on aesthetics, the relationship between consumption and aesthetics, and the effect of Instagram on the aesthetics of women. Because, in previous studies in the literature, different studies have been conducted on Instagram's consumption and its effect on economic relations (Aygül and Gürbüz, 2019, p.162207; Birol, 2014, p.82-92; Bulut, 2020, p.521-539; Demir, 2017, p.277 -287; Demiral and Hassan, 2020, p.361-371; Gökaliler, and Alikılıç 2015, p.120-134; Nardalı and Balkan 2019, p.185-186). The second factor of the scale was named "Perception". This factor includes items that show the rate of women using Instagram, the number of followers, how they feel themselves on Instagram, their desires, feelings, and their perspective towards brands. Brands, which are among the important effects of social media on people, and their effect on people, identity formation, marketing of fashion, communication and perception are available in studies (Armağan, Karakulle and Karademir, 2019, p.2-13; Cukul, 2011, p.116-117; Kuşay, 2014, p.37-38; Özgökbel and Bilis, 2018, p.314-329). The third factor of the scale is named as "Body and Aesthetics". This third factor includes Instagram, consumption and perception, as well as indicators related to body and aesthetics. In this context, borrowing for the body, appearance of the body and happiness, feeling deprivation, traditional values and body relationship, aesthetics and filters, perspective on aesthetic surgeries, aesthetic and bodily risks, Instagram body and expenses, friends' bodies, fashion and desire to own, an investment there are points such as the body as a tool and selfsuffering from the perfection of other bodies. In this regard, in the literature; There are various studies on social media, fashion, identity, selfie applications, instant communication effects, privacy as traditional values, female body and aesthetics. (Değer, 2019, p.166-176; Fidan and Acar Şentürk, 2016, p.6482; Gültekin, 2019, p.345-359; Uzundumlu, 2015, p.227-248).

\section{Research Limitations and Recommendations}

As stated by Karaçam (2015, p.87-97) regarding limitation, interpretation of data to reveal internal and external validity, generalizability, are problems related to theory and methodology. The limitations of this study are, as in other studies, are the limitations of time and costings. In addition, with the pandemic 
period, there were difficulties in reaching the sample, the large study area and the women using Instagram. The study was carried out in a total of four counties and can be done in different groups and university students in different counties. In addition, similar studies on different social media platforms can be explanatory in terms of enlightening the subject and making comparisons.

As a result, the values obtained by using expert opinions, exploratory factor analysis and Cronbach alpha coefficient provide evidence that the measurements to be obtained from the developed measurement tool are reliable and valid. In this context, the effect of Instagram, which is one of the social media tools, on women's body understanding can be determined by using the existing measurement tool.

\section{References}

Akgül, Aziz. Tıbbi Araştırmalarda İstatistiksel Analiz Teknikleri SPSS Uygulamaları. Yükseköğretim Kurulu Matbaası, 1997.

Arklan, Ümit, and Mustafa Akdağ. "Social Media of Daily Life, Daily Life of Social Medya: An Applied Study from Relational and Interactional Perspective." Suleyman Demirel University The Journal of Visionary, vol. 7, no. 16, 2016, pp. 16-34.

Armağan, M. Volkan, et al. "A Research on the Perceptions of Consumers Using Social Media: The Case of Instagram." Eurasian Journal of Researches in Social and Economics, vol. 6, no. 4, 2019.

Aygül, Hasan Huseyin, and Gamze Gürbüz. "Students Wearing Headscarves /Turbans in Terms of Consumption, Fashion and Islamic Clothing: On the Example of Akdeniz University." Muhafazakar Düşünce Dergisi, vol. 15, 2019, pp. 163-209.

Baudrillard, Jean. Tüketim Toplumu: Söylenceleri / Yapıları. Ayrıntı Yayınları, 2016.

Bauman, Zygmunt. Akışkan Modernite. Can Yayinları, 2019.

Balkan, Ece, and Sinan Nardalı. "Marketing through Social Media Influencers: Instagram \& Cosmetic Sector." İmir Katip Çelebi Üniversitesi Iktisadi ve İdari Bilimler
Fakültesi Dergisi, vol. 2, no. 2, 2019, pp. 176187.

Bhandarkar, Ajay M., et al. "Impact of Social Media on the Academic Performance of Undergraduate Medical Students." Medical Journal Armed Forces India, vol. 77, 2021.

Birol, Murat. "A Research on the Decision-Making Styles of Women during their Cloth Shopping in the Framework of their Consumption Patterns." Akdeniz Üniversitesi İletişim Fakültesi Dergisi, vol. 21, 2014, pp. 81-95.

Bourdieu, Pierre. Ayrım: Beğeni Yargısının Toplumsal Eleştirisi, translated by Derya Fırat and Günce Berkkurt, Heretik Yayınları, 2015.

Bulut, Sevim. "Via Social Media - The Effect of Influencer on Marketing Process." Insan ve Sosyal Bilimler Dergisi, vol. 3, no. 1, 2020, pp. 520-541.

Büyüköztürk, Şener. Sosyal Bilimler Için Veri Analizi El Kitabı. Pegem Akademi, 2012.

Castells, Manuel. Enformasyon Çă̆l: Ekonomi, Toplum ve Kültür Cilt 1 A ğ Toplumunun Yükselişi, translated by Ebru Kılıç, Bilgi Üniversitesi Yayınları, 2008.

Castells, Manuel. Isyan ve Umut Ağlarl Internet Çağında Toplumsal Hareketler, translated by Ebru Kılıç, Koç Üniversitesi Yayınları, 2013. Couture Bue, Amelia C. "The Looking Glass Selfie: Instagram Use Frequency Predicts Visual Attention to High-anxiety Body Regions in Young Women." Computers in Human Behavior, vol. 108, 2020.

Crocker, Linda, and James Algina. Introduction to Classical and Modern Test Theory. Wadsworth Publishing, 2006.

Cukul, Dilek. "Social Media as a Tool for Fashion Marketing: Success of Mavi Jeans." Akdeniz Sanat, vol. 4, no. 8, 2011.

Culha, Duygu Gungor. "Summary A Guide to Scale Development and Adaptation in Psychology." Türk Psikoloji Yazılarl, vol. 19, 2016, pp. 104-114.

Dağ, Ahmet. Transhümanizm: Insanın ve Dünyanın Dönüşümü. Elis Publications, 2018.

Değer, Kamuran. "Privacy Use in Social Media: An Evaluation on the Magazine World." Uluslararası Hakemli Sosyal Bilimler 
Dergisi, 2019, pp. 166-176.

Demiral, Nahide, and Azize Hassan. "Women Entrepreneurs and Social Media: A Research on Instagram Pages of Bozcaada Accommodation Businesses." Ankara Hacl Bayram Veli Üniversitesi Turizm Fakültesi Dergisi, vol. 23, no. 2, 2020, pp. 359-373.

Elsaesser, Caitlin, et al. "Small becomes Big, Fast: Adolescent Perceptions of how Social Media Features Escalate Online Conflict to Offline Violence." Children and Youth Services Review, vol. 122, 2021.

Erkuş, Adnan. Psikolojide Ölçme ve Ölçek Geliştirme. Pegem Akademi Yayınları, 2012.

Fidan, Zuhal, and Zulfiye Acar Şentürk. "An Evaluation about Communications and Women at Social Media." Inonu University E-Journal of Faculty of Communication, vol. 1, no. 2, 2016, pp. 64-82.

Field, Andy. Discovering Statistics Using SPSS Statistics. Sage Publications, 2009.

Foucalut, Michel. Cinselliğin Tarihi. Ayrıntı Yayınları, 2015.

Girard, Rene. Kültürün Kökenleri, translated by Mükremin Yaman, Dost Kitabevi Yayınları, 2010.

Gökaliler, Ebru, and Ozlem Alikılıç. "The Role of Social Media in Communication and Branding Process of Woman Entrepreneurs' Companies." Uşak Üniversitesi Sosyal Bilimler Dergisi, vol. 8, no. 1, 2015, pp. 117138.

Gültekin, Metin. "Sociology of Social Media or Instant Communication." The Journal of International Social Sciences, vol. 29, no. 2, 2019, pp. 345-359.

Hardt, Michael, and Antonio Negri. Çokluk. Ayrıntı Yayınlarıv, 2011.

Hardt, Michael, and Antonio Negri. Imparatorluk. Ayrıntı Yayınları, 2012.

Kandil, Zahide. Rol-Model Almada ve Benliğin Sunumunda Yeni Bir Alan Olarak Instagram. Balıkesir Üniversitesi, 2019.

Karaçam, Zekiye. "Writing of Discussion Section and Limitations in the Scientific Research." Ege Üniversitesi Hemşirelik Fakültesi Dergisi, vol. 31, no. 2, 2015, pp. 86-97.
Karasar, Niyazi. Bilimsel Araştırma Yöntemi. Nobel Yayın Dağıtım, 2012.

Kross, Ethan, et al. "Social Media and Well-Being: Pitfalls, Progress, and Next Steps." Trends in Cognitive Sciences, vol. 25, no. 1, 2021, pp. 55-66.

Kuşay, Yeliz. "The Social Media Reflections of Communication Applications of Entities Operating in Sportswear Sector Examples of Nike, Puma and Adidas." AJIT-e: Online Academic Journal of Information Technology, vol. 5, no. 14, 2014.

Lawshe, C.H. "A Quantitative Approach to Content Validity." Personnel Psychology, vol. 28, no. 4, 1975, pp. 563-575.

Manu, Blessing Dwumah, et al. "Student Engagement and Social Media in Tertiary Education: The Perception and Experience from the Ghanaian Public University." Social Sciences \& Humanities Open, vol. 3, no. 1, 2021.

O'Regan, Andrew, et al. "Social Media and Professional Identity: Pitfalls and Potential." Medical Teacher, vol. 40, no. 2, 2018, pp. 112-116.

Özcan Demir, Nilufer. "The Effect of Social Media on Individuals Becoming Consumption Objects." Istanbul Journal of Sociological Studies, no. 55, 2017, pp. 277-288.

Özgökbel Bilis, Pinar. "Representation of Female Identity in the Virtual World Through Profile Photos Used in Facebook." Akdeniz Üniversitesi Illetişim Fakültesi Dergisi, no. 29, 2018, pp. 314-331.

Özmakas, Utku. Biyopolitika; İktidar ve Direniş, İletişim Yayınları, 2018.

Öztürk, Mehmet Fatih, and Mustafa Talas. "Interaction of Social Media and Education." Journal of World of Turks, vol. 7, no. 1, 2015, pp. 101-120.

Pavithra, S., and K.V. Deepak. "The Effect of Social Media on Employees' Job Performance with Reference to Information Technology (IT) Sector in Bangalore." Materials Today: Proceedings, 2021.

Salvucci, Sameena, et al. Measurement Error Studies. National Center for Education Statistics. 1997. 
Sarsar, Firat, et al. "Use of Social Media in Learning and Teaching Process." Mersin University Journal of the Faculty of Education, vol. 11, no. 2, 2015.

Sennet, Richard. Kamusal İnsanın Çöküşü, translated by Serpil Durak and Abdullah Yılmaz, Ayrıntı Yayınlar1, 2013.

Şişman, Nazife. Yeni Insan: Kaderle Tasarım Arasında, Timaş Yayınları, 2012.

Suiçmez, Mehmet. "Otherization of the Female Body in the Media: The Victoria's Secret Example." Middle Black Sea Journal of Communication Studies, vol. 3, no. 2, 2018, pp. 67-84.

Tabachnick, Barbara G., and Linda S. Fidell. Using Multivariate Statistics. Pearson, 2013.

Turan, Adem. The Role of Sharing Photograph in New Social Media on the Construction of Identity: The Case of Instagram. İstanbul Arel Üniversitesi, 2019.

Uzundumlu, Özge. "Bir İletişim Unsuru Olarak Sosyal Selfie Uygulamaları.” Atatürk İletişim
Dergisi, no. 8, 2015, pp. 227-248.

Wilson, F. Robert, et al. "Recalculation of the Critical Values for Lawshe's Content Validity Ratio." Measurement and Evaluation in Counseling and Development, vol. 45, no. 3, 2012, pp. 197-210.

Yıldırım, Ozam, and Idil İpek. "Internet and Social Media Use in the Period of Social Isolation and Voluntary Quarantine which comes to the Agenda Due to the New Coronavirus Outbreak." Illetişim Kuram ve Araştırma Dergisi, no. 52, 2020, pp. 69-94.

Zümrüt, Secil. Sosyal Medya Reklamlarının Tüketici Davranışına Etkisi Instagram Kullanıcıları Üzerine Bir Çalışma. Nuh Naci Yazgan Üniversitesi, 2016.

"2020 Sosyal Medya Kullanıcı Sayıları.” MedyaAkademi, 2020, https://medyaakademi. com.tr/2020/02/03/2020-sosyal-medyakullanici-sayilari

\section{Author Details}

Nuray Karaca, Prof. Dr., Atatürk University, Turkey, Email ID: nkaraca@atauni.edu.tr.

Abdulselami Sarı̈ül, Lecturer, Ağrı İbrahim Çeçen University, Turkey, Email ID: selamisarigul@hotmail.com. 